\title{
PENGELOLAAN DANA PEMERINTAH DESA: KAJIAN PADA KECAMATAN BABAKAN MADANG, SUKARAJA DAN CIAWI
}

\section{THE MANAGEMENT OF VILLAGE GOVERNMENT FUND : STUDY IN THE BABAKAN MADANG, SUKARAJA AND CIAWI}

M.N. Mukmin, S. Maemunah

Program Studi Akuntansi Fakultas Ekonomi Universitas Djuanda Bogor

Jl. Tol Ciawi No. 1 Kotak Pos 35, Kode Pos 16720, Telp/Fax : (0251) 8245155

Email : siti.maemunah@unida.ac.id

\begin{abstract}
Besicall the government is spending village funds is to finance government programs in the welfare of the comunity. Village found management the principle of transparency of accountabillity and participation. The method of this research design is using methods with descriptive associative. The population in this research were 28. With using purposive sampling technicque. The data were analyzed by multiple linear regression. the result all data is valid and reliable, and the model in this research is worth. While the result of the analysis and hypotesis testing, showed that simultan test of partial test. Transparancy, accountability and participation significant impact on the managemen of village government fund in the Babakan madang, Sukaraja and Ciawi. The contribution effect of tranparancy, accountability and participation on the managemen of village government fund in the Babakan madang, Sukaraja and Ciawi is 51,1 percen
\end{abstract}

Keyword: Transparancy, Accountability, Participation, managemen of village government fund

\begin{abstract}
ABSTRAK
Pada dasarnya pemerintah mengeluarkan Dana Desa adalah untuk membiayai programprogram pemerintah dalam mensejahterakan masyarakat. Sehingga pengelolaan dana desa dilakukan dengan asas transparansi, akuntabilitas dan partisipasi. Desain penelitian ini menggunakan metode survey yang bersifat asosiatif. Populasi penelitian sebanyak 280 populasi dengan teknik pengambilan sampel menggunakan purposive sampling. Pengujian dan analisis data menggunakan analisis regresi linear berganda dan semua instrumen dalam penelitian ini valid dan reliabel. Hasil analisis dan pengujian hipotesis yang dilakukan menunjukan bahwa secara simultan maupun parsial transparansi, akuntabilitas dan partisipasi berpengaruh signifikan terhadap pengelolaan dana pemerintah desa pada kecamatan babakan madang, kecamatan sukaraja dan kecamatan ciawi. Besarnya kontribusi pengaruh transparansi, akuntabilitas dan partisipasi terhadap pengelolaan dana pemerintah desa yaitu sebesar 51,1 persen.
\end{abstract}

Kata kunci: $\quad$ Transparansi, Akuntabilitas, Partisipasi, Pengelolaan Dana Pemerintah Desa 


\section{PENDAHULUAN}

Perkembangan akuntansi sektor publik bagitu cepat, terutama dalam pelaksanaan kebijakan otonomi daerah. Otonomi daerah merupakan suatu cara pemberdayaan daerah untuk pengambilan ketentuan daerah agar lebih bebas serta bertanggungjawab untuk mengelola sumberdaya yang dimiliki sesuai dengan kebutuhan, kemampuan daerah sendiri. Penyelenggaran otonomi daerah wajib mengarah pada peningkatan kesejahteraan dengan memperhatikan kepentingankepentingan serta aspirasi masyarakat.

UU desa menciptakan energi baru dalam upaya membangun Indonesia menjadi lebih baik. walaupun desa adalah tingkat pemerintahan paling rendah di Indonesia, tetapi membangun Indonesia tanpa melibatkan desa di dalamnya merupakan hal sangat disayangkan. Desa merupakan identitas pemrintahan yang berkaitan langsung dengan rakyat, tetapi secara geografis berjarak jauh dari pusat kekuasaan di atasnya. Hal itu menyebabkan desa memiliki arti penting sebagai basis pelaksana pelayanan publik dan menyediakan pemenuhan hak-hak publik rakyat lokal. Sebagai penyelenggara publik pemerintah desa diberikan kewenangan untuk mengatur keuangannya sendiri yang bersumber dari dana desa.

Serasi dengan UU No. 6 Tahun 2014 mengenai desa, Pemerintah mengalokasikan dana desa, dengan proses transfer pada Kabupaten/Kota. Berdasarkan alokasi dana tersebut, tiap Kabupaten/Kota mendistribusikan kepada setiap desa berlandaskan jumlah desa serta memperhatikan jumlah penduduk (30\%), luas wilayah (20\%), dan angka kemiskinan (50\%). Hasil perhitungan tersebut disesuaikan juga dengan taraf kerumitan geografis masing-masing desa. Alokasi anggaran seperti dijelaskan di atas, berasal dari Belanja Pusat dengan mengaktifkan program yang berbasis desa dengan menyeluruh dan berkeadilan. Besarnya distribusi anggaran yang diperuntukan ke desa ditentukan 10 persen dari dana di luar dana transfer daerah secara bertahap. Permendagri No 113 Thn 2014 menyatakan bahwa keuangan desa di lakukan dengan asas transparansi, akuntabilitas dan partisipasi serta dilaksanakan dengan tertib dan disiplin anggaran

Berdasarkan pernyataan tersebut pemerintah desa dituntut agar meningkatkan transparan dan akuntabel dalam proses perencanaan sampai proses pertanggungjawabaan selain itu masyarakat maupun lembaga lain dalam setiap kegiatan harus di ikut sertakan agar terhindari dari terjadinya kecurangan. Namun masih ada yang harus dibenahi dari ketiga asas tersebut, banyak masyarakat yang merasa bahwa pengelolaan kuangan desa kurang mengikut sertakan masyarakat, selain itu masyarakat masih belum merasakan pengaruh positif dari adanya dana desa tersebut, sehingga masyarakat berfikir bahwa aparat desa dalam pengelolaannya kurang transparansi, akuntabel serta partisipasif.

Pada dasarnya pemerintah mengeluarkan anggaran adalah untuk membiayai program pemerintah dalam mensejahterakan masyarakat, sehingga dengan adanya dana desa setiap program pemerintah dapat terlaksana dengan lebih mudah. Namun disisi positifnya Dana Desa justru membuka peluang untuk pihak yang memiliki kepentingan pribadi untuk berlaku curang, sehingga anggaran desa yang seharunya dipergunakan seluruhnya untuk kepentingan umum justru malah di pergunakan untuk kebutuhan sendiri sedangkan untuk kepentingan umum hanya sekadarnya saja, yang lebih memperihatinkannya lagi penyalah gunaan Dana Desa sering dilakukan oleh 
pihak yang dinaggap amanah, atau oleh pihak pemimpin masyarakat, selain itu kurangngnya tingkat pengetahuan tentang akuntansi oleh aparat desa dapat memberikan peluang besar untuk menjalankan manipulasi dana tersebut.

\section{Tinjauan Pustaka dan Pengembangan Hipotesis \\ Pengertian Akuntansi Sektor Publik}

Bastian (2010:3) menyatakan bahwa akuntansi sektor publik ialah mekanisme teknis serta kajian akuntansi yang diterapkan pada pengelolaan dana masyarakat di lembaga tinggi negara dan departemen dibawahnya, pemerintah daerah, BUMN, BUMD, LSM \& yayasan sosial, maupun pada proyek kerjasama sektor publik \& swasta.

\section{Pengertian Akuntansi Desa}

Sujarweni ( 2015 :1) Akuntansi merupakan suatu kegiatan jasa yang terdiri dari mencatat, mengklasifikasikan, \& melaporkan kejadian atau transaksi ekonomi yang akhirnya akan menghasilkan suatu informasi keuangan yang akan diperlukan oleh pihak-pihak tertentu untuk pengambilan keputusan.

\section{Pengertian transparansi}

Transparansi merupakan keterbukaan dalam memberikan informasi tanpa ada yang ditutup-tutupi oleh pengelola kepada pemangku kepentingan. Transparansi memiliki beberapa dimensi. Dimensi transparansi menurut Mardiasmo (2009:19) yaitu:

1. Invormativeness (informatif)

2. Disclosure (pengungkapan)

\section{Pengertian Akuntabilitas Publik}

Akuntabilitas publik merupakan kewajiban pemegang amanah dalam memberikan pertanggungjawaban, menyajikan, melaporkan \& mengungkap segala kegiatan dan menjadi tanggungjawab kepada pemberi amanah yang memiliki hak dan kewenangan untuk meminta pertanggungjawaban tersebut (Marsiasmo, 2002:20).

Mardiasmo menjelaskan terdapat empat dimensi akuntabilitas yang perlu dipenuhi oleh organisasi sektor publik, yatu:

1. Akuntabilitas kejujuran dan akuntabilitas hukum

2. Akuntabilitas proses

3. Akuntabilitas program

4. Akuntabilitas kebijakan

\section{Pengertian Partisipasi}

UNDP (United Nation Development Program) dalam Mardiasmo (2002:18) Pertisipasi (Participation) ialah keikutsertaan masyarakat dalam penyusunan keputusan baik secara langsung maupun tidak langsung melalui lembaga perwakilan yang dapat menyalurkan aspirasinya. Partisipasi tersebut dibangun atas dasar

1. Kebebasan berasosiasi

2. Kebebasan berbicara

3. Berpartisipasi secara konstruktif.

\section{Pengertian Dana Desa}

Pasal 1 angka 2 PP No. 8 Tahun 2016 Dana Desa yakni dana yang bersumber dari APBN yang diperuntukkan bagi Desa yang ditransfer melalui APBD kota/kabupaten \& digunakan untuk membiayai penyelenggaraan pemerintahan, pelaksanaan, pembangunan, dan pemberdayaan masyarakat.

Dari pengertian berikut dijelaskan dana desa diperuntukan bagi pembiayaan penyelenggaraan pemerintahan, pelaksanaan pembangunan, pembinaan kemasyarakatan, serta pemberdayaan masyarakat. Tetapi, dana desa diprioritaskan dalam membiayaan pembangunan \& pemberdayaan masyarakat.

\section{Pengelolaan Dana Pemerintah Desa}

Pengelolaan keuangan desa merupakan segala bentuk kegiatan administratif yang dilakukan dalam bentuk 
beberapa tahapan. Pengelolaan keuangan desa meliputi:

1. Perencanaan

2. Pelaksanaan

3. Penatausahaan

4. Pelaporan

5. Pertanggungjawaban

\section{Pengembagan Hipotesis}

Pengaruh Transparansi Terhadap Pengelolaan Dana Pemerintah Desa

Transparansi ialah aspek mendasar bagi terwujudnya penyelenggaraan pemerintahan yang baik. terwujudnya tata pemerintahan yang baik membuktikan adanya keterbukaan, keikutsertaan, dan kemudahan akses bagi masyarakat dalam penyelenggaraan pemerintah. Keterbukaan \& kemudahan informasi penyelenggaran pemerintahan memberikan pengaruh untuk mewujudkan berbagai indikator lainnya.

Hipotesis pertama sebagai berikut:

$\mathrm{H}_{1}$ : Diduga Transparansi berpngaruh positif dan signifikan terhadap pengelolaan dana pemerintah desa.

\section{Pengaruh Akuntabilitas Terhadap Pengelolaan Dana Pemerintah Desa}

Akuntabilitas publik memiliki peran penting pada pelaksanaan kegiatan pemerintahan karena penyelenggaraan akuntabiilitas sektor publik bertujuan memberikan pertanggungjawaban kepada masyarakat karena sumber dana yang digunakan berasal dari masyarakat.

Hipotesis yang kedua sebagai berikut:

$\mathrm{H}_{2}$ : Diduga akuntabilitas brpengaruh positif signifikan terhada pengelolaan dana pemerintah desa.

\section{Pengaruh Partisipasi Terhadap Pengelolaan Dana Pemerintah Desa}

Partisipasi masyarakat dalam kegiatan yang diadakan pemerintah tergantung pada sejauhmana pemerintah mengajak masyarakat untuk langsung ikut serta disetiap kegiatan yang diadakannya. Partisipasi masyarakat sangat dibutuhkan agar terhindari dari terjadinya kesalahpahaman dalam setiap kegiatan selain itu partisipasi masyarakat merupakan sala satu asas dalam pengelolaan dana desa. Hipotesis yang ketiga sebagai berikut:

$\mathrm{H}_{3}$ : Diduga partisipasi berpengaruh positif signifikan trhadap pengelolaan dana pemerintah desa.

\section{METODE PENELITIAN}

Penelitian ini berkenaan dengan transparansi, akuntabilitas dan partisipasi terhadap pengelolaan dana pemerintah desa. Pada wilayah Kecamatan Babakan Madang, Sukaraja dan Ciawi.

Data yang digunakan pada penelitian ini adalah asosiatif, yakni penelitian yang menguji hubungan atau hubungan antara variabel, dua variabel atau lebih.

Penelitian ini menggunakan data kuantitatif. Sarosa (2012), penelitian kuantitatif ialah penelitian yang menggunakan pengukuran kuantitatif untuk menguji hipotesis dengan tujuan menemukan generalisasi dan menekankan pada pengukuran dan analisis hubungan sebab akibat diantara variabel.

\section{Variabel Penelitian Dan Definisi Oprasional variabel}

Variabel Independen dalam penelitian ini ialah Transparansi, Akuntabilitas dan Partisipasi. Sedangkan variabel dependennya ialah Pengelolaan Dana Pemerintah Desa. Berikut ini adalah tabel 1 oprasional variabel 


\begin{tabular}{|c|c|c|c|}
\hline Variabel & Konsep Variabel & $\begin{array}{r}\text { Indikator } \\
\end{array}$ & Sekala \\
\hline $\begin{array}{l}\text { Transparansi } \\
\left(\mathrm{X}_{1}\right)\end{array}$ & $\begin{array}{l}\text { Transparansi merupakan keterbukaan } \\
\text { dalam memberikan informasi tanpa ada } \\
\text { yang dirahasiakan oleh pengelola } \\
\text { kepada para pemangku kepentingan. } \\
\text { (Mardiasmo 2009:19) }\end{array}$ & 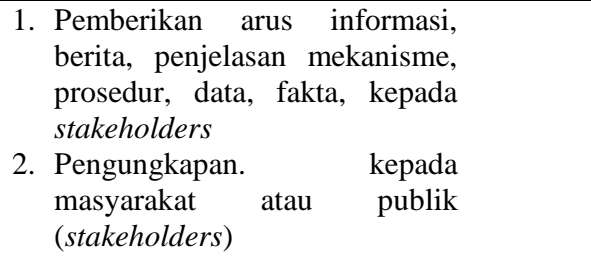 & Ordinal \\
\hline $\begin{array}{l}\text { Akuntabilitas } \\
\left(\mathrm{X}_{2}\right)\end{array}$ & $\begin{array}{l}\text { Akuntabilitas publik merupakan } \\
\text { kewajiban pemegang amanah untuk } \\
\text { memberikan pertanggungjawaban, } \\
\text { menyajikan, melaporkan dan } \\
\text { mengungkap segala kegiatan yang } \\
\text { menjadi tanggungjawabnya kepada } \\
\text { pemberi amanah yang memiliki hak dan } \\
\text { kewenangan untuk meminta } \\
\text { pertanggungjawaban } \\
\text { (Mardiasmo, 2002:20). }\end{array}$ & $\begin{array}{l}\text { 1. Akuntabilitas Hukum dan akuntabilitas } \\
\text { kejujuran } \\
\text { 2. Akuntabilitas Proses } \\
\text { 3. Akuntabilitas Program } \\
\text { 4. Akuntabilitas Kebijakan }\end{array}$ & $\begin{array}{l}\text { Ordinal } \\
\text { Ordinal } \\
\text { Ordinal } \\
\text { Ordinal }\end{array}$ \\
\hline $\begin{array}{l}\text { Partisipasi } \\
\left(\mathrm{X}_{3}\right)\end{array}$ & $\begin{array}{l}\text { Partisipasi ialah Keikutsertaan } \\
\text { masyarakat untuk membuat keputusan } \\
\text { baik langsung maupun tidak langsung } \\
\text { melalui lembaga perwakilan yang dapat } \\
\text { menyalurkan aspirasinya. } \\
\text {. (Mardiasmo, 2002:18) }\end{array}$ & $\begin{array}{l}\text { 1. Kebebasan berasosiasi } \\
\text { 2. Kebebasan berbicara } \\
\text { 3. berpartisipasi secara konstruktif. }\end{array}$ & $\begin{array}{l}\text { Ordinal } \\
\text { Ordinal } \\
\text { Ordinal }\end{array}$ \\
\hline $\begin{array}{l}\text { Pengelolaan } \\
\text { Dana } \\
\text { Pemerintah } \\
\text { Desa (Y) }\end{array}$ & $\begin{array}{l}\text { Pengelolaan Dana Pemerintah Desa } \\
\text { merupakan pengelolaan keuangan Desa. } \\
\text { Pengelolaan keuangan ialah segala } \\
\text { bentuk kegiatan administratif yang } \\
\text { dilakukan dalam bentuk beberapa } \\
\text { tahapan. } \\
\text { (Permendagri No. } 113 \text { Tahun 2014) }\end{array}$ & $\begin{array}{l}\text { 1. Perencanaan } \\
\text { 2. Pelaksanaan } \\
\text { 3. Penatausahaan } \\
\text { 4. Pelaporan } \\
\text { 5. Pertanggungjawaban }\end{array}$ & $\begin{array}{l}\text { Ordinal } \\
\text { Ordinal } \\
\text { Ordinal } \\
\text { Ordinal } \\
\text { Ordinal }\end{array}$ \\
\hline
\end{tabular}

\section{Populasi dan Sampel Penelitian}

Populasi penelitian ini merupakan perangkat desa sebanyak 280 yang terdapat pada wilayah Kecamatan Babakan Madang, Sukaraja dan Ciawi.

Teknik pengambilan sampel menggunakan teknik porposive sampling. Menurut Sugiyono (2016:96) purposive sampling adalah teknik penetuan sampel dengan pertimbangan tertentu. Sehingga dari 280 populasi setelah dipurposive menghasilkan 140 sampel

\section{Pengujian Data}

Instrumen untuk mengukur ketiga variabel dalam penelitian menggunakan kuesioner. Responden akan menilai setiap pernyataan dengan menggunakn skal likert 5 poin, dari persepsi responden bahwa responden sangat tidak setuju sampai setuju terhadap suatu pernyataan yang ada pada kuisioner. Untuk tujuan analisis kuantitatif, lalu jawaban diberi skor.

Tabel 2 Penilaian Kuesioner

\begin{tabular}{|c|c|}
\hline Jawaban Responden & Bobot Nilai \\
\hline Sangat Setuju & 5 \\
\hline Setuju & 4 \\
\hline Ragu-ragu & 3 \\
\hline Tidak Setuju & 2 \\
\hline Sangat tidak setuju & 1 \\
\hline \multicolumn{2}{|l|}{ Sumber : Sugiyono, 2013} \\
\hline sebagai berikut & penilaian \\
\hline \multicolumn{2}{|c|}{ Tabel 3 Skala Penilaian } \\
\hline Skala & Interpresentasi \\
\hline $1,00-1,80$ & Sangat tidak setuju \\
\hline $1,81-2,60$ & Tidak setuju \\
\hline $2,61-3,40$ & Ragu-ragu \\
\hline $3,41-4,20$ & Setuju \\
\hline $4,21-5,00$ & Sangat setuju \\
\hline
\end{tabular}

Sumber : Sugiyono, 2014 


\section{Uji Validitas}

Sebelum kuisioner digunakan untuk mengkumpulkan data, terlebih dahulu diuji validitasnya kepada responden, dengan memakai rumus teknik korelasi "product moment” (Sugiyono, 2013:183), sebagai berikut:

$$
\mathrm{r}=\frac{N\left(\sum x y\right)-\left(\sum x \sum y\right)}{\sqrt{\left.\left(N \sum x^{2}\right)-\left(N \sum x\right)^{2}\left(N \sum y^{2}\right)-\left(\sum y\right)^{2}\right)}}
$$

Dimana:

$\mathrm{r}=$ Keofisien validitas item yang dicari

$\mathrm{x}=$ Skor yang diperoleh dari subyek dalam tiap item

$\mathrm{y}=$ Skor total yang diperoleh dari subyek seluruh item.

$\sum \mathrm{x}=$ Jumlah skor dalam distribusi $\mathrm{x}$

$\sum \mathrm{x}^{2}=$ Jumlah kuadrat pada masingmasing $\mathrm{x}$

$\sum \mathrm{y} 2=$ Jumlah kuadrat pada masingmasing y

$\mathrm{N}=$ Jumlah responden.

Tabel 4 Kriteria Uji Validitas

\begin{tabular}{cc}
\hline $\begin{array}{c}\text { Corrected Item Total } \\
\text { Corelation }\end{array}$ & Keterangan \\
\hline$\geq 0,3$ & Valid \\
$<0,3$ & Tidak Valid \\
\hline
\end{tabular}

Sumber : Sugiyono, 2013

\section{Uji reliabilitas}

Untuk mengukur Relibilitas dalam penelitian ini memakai teknik cronbach. (Gozali,2011:45). Rumus teknik cronbach sebagai berikut:

$$
r 11=\left[\frac{k}{k-1}\right]\left[\frac{\sum \sigma_{b}^{2}}{1-\sigma_{t}^{2}}\right]
$$

Dimana:

r11 = reliabilitas instrumen

$\mathrm{k}=$ banyak butir pertanyaan

$\sigma_{t}^{2}=$ Varian Total

$\sum \sigma_{b}^{2}=$ Jumlah Varian Butir

berikut ini ialah tabel untuk kriteria uji reliabilitas.

Tabel 5 Kriteria UjiReliabilitas

\begin{tabular}{cc}
\hline Alpha Cronbach & Keterangan \\
\hline$>0,6$ & Reliabel \\
$<0,6$ & Tidak Reliabel \\
\hline
\end{tabular}

Sumber : Sugiyono, 2013

Uji Asumsi Klasik
Sebelum melakukan pengujian hipotesis, dilakukan uji asumsi klasik terlebih dahulu yang mendasari dan menjadi persyaratan statistik yang perlu dipenuhi dalam penggunaan analisis regresi dan koefesien regresi yang linier, tidak bias, konsisten, serta efisien. Asumsi klasik menurut Ghozali (2011) adalah uji normalitas, uji multikolonieritas dan uji hateroskedastistas.

\section{Metode Pengolahan dan Analisis Data}

Regresi linear berganda Sugiyono

(2013:206) adalah sebagai berikut:

$$
Y=a+\beta_{1} X_{1}+\beta_{2} X_{2}+\beta_{3} X_{3}+\varepsilon
$$

Dimana:

$\mathrm{Y}=$ kepatuhan wajib pajak

$\mathrm{a} \quad=$ nilai konstanta

$\mathrm{X} 1$ = Transparansi

$\mathrm{X} 2$ = Akuntabilitas

$\mathrm{X} 3$ = Partisipasi

$\varepsilon \quad=$ faktor lain yang diteliti

$\beta_{1}=$ koefisien regresi variabel $\mathrm{x}_{1}$

$\beta_{2}=$ koefisien regresi variabel $x_{2}$

$\beta_{3}=$ koefisien regresi variabel $x_{3}$

koefesien korelasi berganda alat ini digunakan untuk mengukur tingkat hubungan antara variabel-variabel bebas (X) terhadap variabel terikat (Y).

Tabel 6 Pedoman untuk interprestasi koefisien korelasi

\begin{tabular}{cc}
\hline Interval Nilai r & Interprestasi \\
\hline $0,001-0,200$ & Sangat Lemah \\
$0,201-0,400$ & Lemah \\
$0,401-0,600$ & Cukup Kuat \\
$0,601-0,800$ & Kuat \\
$0,801-1,000$ & Sangat Kuat \\
\hline
\end{tabular}

Sumber : Sugiyono, 2010

\section{Uji Hipotesis}

\section{Uji Simultan (F-test)}

Langkah-langkah

pengujian menggunakan uji $\mathrm{F}$ yaitu sebagai berikut:

a. Tingkat signifikansi sebesar $\alpha=5 \%$

Perumusan hipotesis uji $\mathrm{F}$ adalah:

$\mathrm{H}_{0}: \beta_{1}, \beta_{2}, \beta_{3}=0 ; \quad$ Transpaaransi,

Akuntablitas dan Partiisipasi tidak terdapat peengaruh secra siimultan terhadap pengelolaan dana pemerintah desa

$\mathrm{H}_{\mathrm{a}}: \beta_{1}, \beta_{2}, \beta_{3} \neq 0 ; \quad$ Trnsparansi,

Akuntbilitas dan Partisiipasi terdapat 
pngaruh scara simultn terhadap pengelolaan dana pemerintah desa

b. Menghitung uji F (F-test)

$$
F_{\text {hitung }}=\frac{R^{2}-k-1}{\left(1-R^{2}\right) /(n-k)}
$$

Keteraangan:

$\mathrm{R}^{2}$ :koefisien determinasi gabungan

$\mathrm{k}$ : jumlah variabel independen

$\mathrm{n}$ : jumlah sampel

c. kriteria pengambilan keputusan

1) jika $\left(F_{\text {hitung }}>F_{\text {tabel }}\right)$ denagn $\alpha=0,05$ maka $\mathrm{H}_{\mathrm{o}}$ diitolak dan $\mathrm{H}_{\mathrm{a}}$ ditrima

2) jika $\left(\mathrm{F}_{\text {hitung }} \leq \mathrm{F}_{\text {tabel }}\right)$ denagn $\alpha=0,05$ maka $\mathrm{H}_{\mathrm{o}}$ diterima dan $\mathrm{H}_{\mathrm{a}}$ ditolaak

\section{Uji Parsial (T-test)}

Langkah-langkah pengujian dengan menggunakan uji t adalah sebagai berikut:

a. Menentukan tingkat signifikansi sebesar $\alpha=5 \%$

Perumusan hipotesis uji $\mathrm{F}$ adalah:

$\mathrm{H}_{0}: \beta_{1}=0$;Transparansi tidak berpengaruh secara prsial terhadp pengelolan dana pemerintah desa.

$\mathrm{H}_{\mathrm{a}}: \beta_{1} \neq 0$; Transparansi brpengaruh secara parsial terhadp pengelolaan dana pemerintah desa.

$\mathrm{H}_{0}: \beta_{2}=0$; Akuntabilitas tidak berpengaruh secara parsial terhadap pengelolan dana pemerintah desa.

$\mathrm{H}_{\mathrm{a}}: \beta_{2} \neq 0$;Akuntabilitas berpengaruh secara parsial terhadap pengelolaan dana pemerintah desa.

$\mathrm{H}_{0}: \beta_{3}=0$; Partisipasi tidak brpengaruh secara parsial terhadp pengelolan dana pemerintah desa.a

$\mathrm{H}_{\mathrm{a}}: \beta_{3} \neq 0$; Partisipasi berpengarh scara parsial trhadap pengelolan dana pemerintah desa.

$$
\mathrm{T}_{\text {hitung }}=\frac{\mathrm{r} \sqrt{\mathrm{n}-2}}{1-\mathrm{r}^{2}}
$$

Keterangan:

t: hitung yang selanjutnya dibandingkan dengan $t$ tabel

$\mathrm{r}$ : koefisien korelasi

$\mathrm{n}$ : jumlah sampel

c. kriteria pengambilan keputusan

1. Untuk transparansi jika ( $\mathrm{t}_{\text {hitung }} \leq \mathrm{t}_{\text {tabel }}$ ) pada $\alpha=0,05$ maka $\mathrm{H}_{\mathrm{o}}$ dterima dan $\mathrm{H}_{\mathrm{a}}$ dtolak. Begitu sebaliknya.

2. Untuk akuntabilitas jika ( $\left.\mathrm{t}_{\text {hitung }} \leq \mathrm{t}_{\text {tabel }}\right)$ pada $\alpha=0,05$ maka $\mathrm{H}_{\mathrm{o}}$ diterma dan $\mathrm{H}_{\mathrm{a}}$ ditolk. Begitu sebaliknya

3. Untuk partisipasi jika (thitung $\leq$

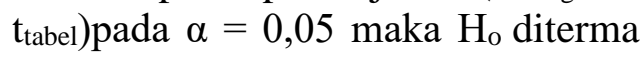
dan $\mathrm{H}_{\mathrm{a}}$ ditolk. Begitu sebaliknya Adapun bentuk pengujian hipotesis yang digunakan yaitu uji dua pihak (Two Tail Test) terlihat pada Gambar 1 berikt ini :

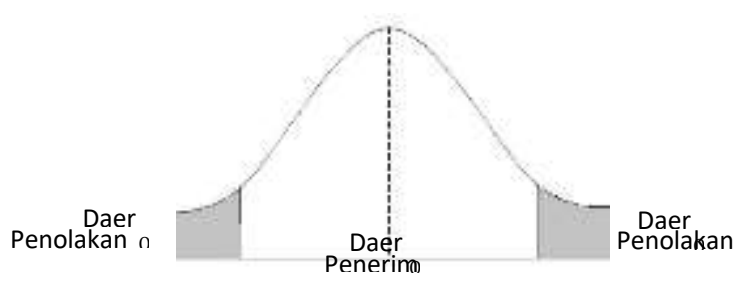

Sumber : Sugiyono (2013: 217)

\section{Koefisien Determinasi}

Analisis koefisien determinasi ( $\mathrm{R}$ Square/ $\mathrm{R}^{2}$ ) digunakan untuk mengetahui persentase sumbangan 
variabel $\mathrm{X}_{1}, \mathrm{X}_{2}$ dan $\mathrm{X}_{3}$ terhadap $\mathrm{Y}$ (Sugiyono 2012;257). Rumus yang digunakan yaitu:

$K D=r^{2} \times 100 \%$

Keterangan :

$\mathrm{KD}=$ Koefisien Determinasi

$\mathrm{r}^{2}=$ Koefisien korelasi

\section{HASIL DAN PEMBAHASAN \\ Karakteristik Responden}

Jumlah responden yang dijadikan sampel adalah 140 responden dari setiap kantor desa masing-masing terdiri dari Kepala Desa, Sekretaris Desa, Bendahara Desa dan Kepala BPD (Badan Permusyawaratan Desa) yang berada pada daerah Kecamatan Babakan Madang, Kecamatan Sukaraja \& Kecamatan Ciawi. Kuesioner pada penelitian ini sebanyak 140 tetapi yang kembali hanya sebanyak 120 kuesioner. Untuk menggambarkan karakteristik responden maka dilakukan deskriptif penelitian berdasarkan atas pengelompokan menurut jenis kelamin, usia, masa kerja \& pendidikan.

Rekapitulasi untuk karakteristik responden yang telah dikelompokan disajikan pada tabel 7 berikut:

Tabel 7 Rekapitulasi Karakteristik

Responden

\begin{tabular}{cccc}
\hline No & $\begin{array}{c}\text { Kriteria } \\
\text { Responden }\end{array}$ & Karakteristik & Jumlah/orang \\
\hline 1 & Jenis Klamin & Laki-laki & $93(77,5 \%)$ \\
2 & Usia & $31-40 \mathrm{Th}$ & $45(37 \%)$ \\
3 & Masa Kerja & $>4 \mathrm{Th}$ & $73(61 \%)$ \\
4 & Tingkat & SMA & $81(67,5 \%)$ \\
& Pendidikan & & \\
\hline
\end{tabular}

Sumber: Data diolah, 2017

\section{Tanggapan Responden}

Tabel 8 Rekapitulasi Tanggapan Responden

\begin{tabular}{|c|c|c|c|}
\hline No & Variabel & $\begin{array}{l}\text { Nilai } \\
\text { Rata- } \\
\text { rata } \\
\end{array}$ & $\begin{array}{l}\text { Keterangan } \\
\text { Skor } \\
\text { Tanggapan } \\
\end{array}$ \\
\hline 1 & Transparansi & 4,45 & $\begin{array}{l}\text { Sangat } \\
\text { Setuju }\end{array}$ \\
\hline 2 & Akuntabilitas & 4,41 & $\begin{array}{l}\text { Sangat } \\
\text { Setuju }\end{array}$ \\
\hline 3 & Partisipasi & 4,47 & $\begin{array}{l}\text { Sangat } \\
\text { Setuju }\end{array}$ \\
\hline 4 & $\begin{array}{l}\text { Pengelolaan } \\
\text { Dana } \\
\text { Pemerintah } \\
\text { Desa }\end{array}$ & 4,5 & Setuju \\
\hline
\end{tabular}

Sumber : Data diolah, 2017

Berdasarkan tabel 8 tersebut, diambil kesimpulkan bahwa jawaban responden untuk variabel transparansi yaitu memiliki nilai rata-rata skor tanggapan sebesar 4,45 dengan keterangan rata-rata sangat setuju dengan pernyataan yang diajukan pada kuesioner. Jawaban untuk variabel akuntabilitas yaitu memiliki nilai rata-rata skor tanggapan sebesar 4,41 dengan keterangan rata-rata sangat setuju dengan pernyataan yang diajukan dalam kuesioner. Selanjutnya untuk variabel partisipasi memiliki jawaban rata-rata skor tanggapan sebesar 4,47

dengan keterangan rata-rata sangat setuju dengan pernyataan yang diajukan dalam kuesioner. Selanjutnya untuk variabel pengelolaan dana pemerintah desa jawaban responden memiliki rata-rata skor tanggapan sebesar 4,5 dengan keterangan rata-rata responden setuju dengan pernyataan yang diajukan pada kuesioner. Sehingga dapat disimpulkan, rata-rata responden sangat setuju bahwa transparansi, akuntabilitas, dan partisipasi akan mempengaruhi pengelolaan dana pemerintah desa pada kecamatan babakan madang, kecamatan sukaraja \& kecamatan ciawi 
Persamaan Regresi Linear Berganda

Hasil persamaan regresi linear berganda

adalah sebagai berikut:

Tabel 9 Analisis Regresi Linear Berganda

Coeficients $^{a}$

\begin{tabular}{|c|c|c|c|c|c|}
\hline \multirow[b]{2}{*}{ Model } & \multicolumn{2}{|c|}{ Unstandardized Coefficients } & $\begin{array}{l}\text { Standardized } \\
\text { Coefficients } \\
\end{array}$ & \multirow[b]{2}{*}{$\mathrm{T}$} & \multirow[b]{2}{*}{ Sig. } \\
\hline & $\mathrm{B}$ & Std. Error & Beta & & \\
\hline 1 (Constant) & -3.722 & 4.162 & & -.894 & .373 \\
\hline Transparansi & .394 & .081 & .442 & 4.861 & .000 \\
\hline Akuntabilitas & .249 & .090 & .234 & 2.752 & .007 \\
\hline Partisipasi & 3.890 & 1.842 & .160 & 2.112 & .037 \\
\hline
\end{tabular}

Sumber: Output pengolahan data dengan SPSS 22, 2017

Berdasarkan tabel 9 tersebut

diketahui bahwa nilai dari persamaan

regresi yaitu sebagai berikut :

$$
\begin{aligned}
\mathrm{Y}= & \mathrm{a}+\beta_{1} \mathrm{X}_{1}+\beta_{2} \mathrm{X}_{2}+\beta_{3} \mathrm{X}_{3}+\varepsilon \\
\mathrm{Y}= & -3.722+0,394 \mathrm{X}_{1}+0,249 \mathrm{X}_{2}+ \\
& 3.890 \mathrm{X}_{3}+\varepsilon
\end{aligned}
$$

\section{Koefisien Korelasi Berganda}

Analisis koefisien korelasi berganda digunakan untuk mengatahui derajat kekuatan hubungan antara transparansi, akuntabilitas dan partisipasi secara bersama-sama terhadap pengelolaan dana pemerintah desa. Adapun tabel koefisien korelasi sebagai berikut :

Tabel 10 Koefesien Korelasi Berganda Model Summary ${ }^{\mathrm{b}}$

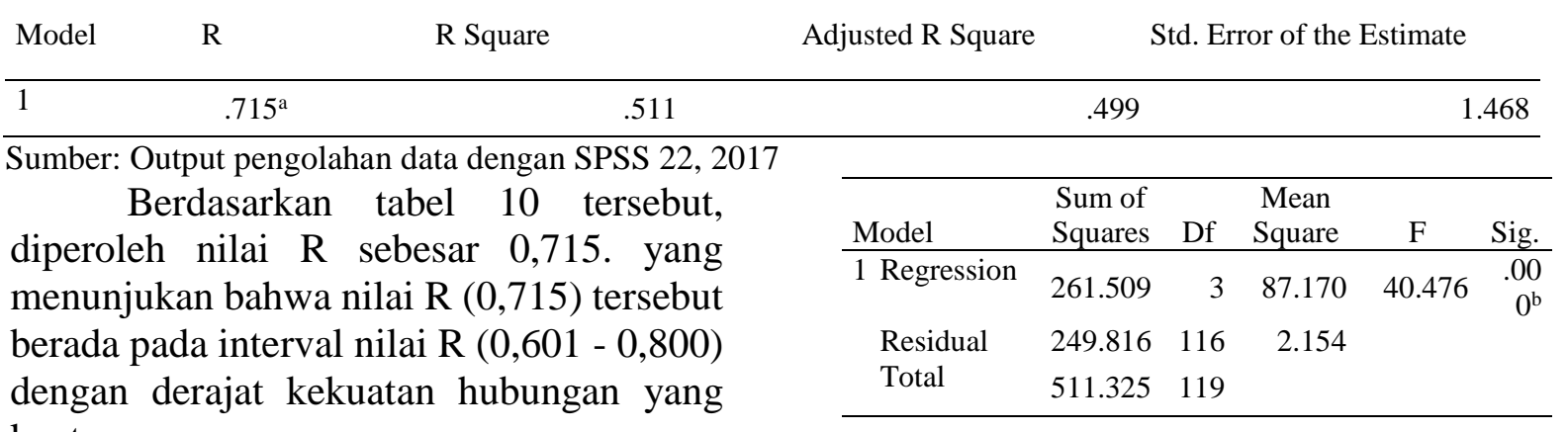

\section{Pengujian Hipotesisi}

1. Pengaruh Transparansi, Akuntabilitas dan Partisipasi Secara Simultan Terhadap Pengelolaan Dana Pemerintah Desa.

Pengujian ini dilakukan untuk mengetahui pengaruh secara simultan penerapan transparansi, akuntabilitas dan partisipasi terhadap pengelolaan dana pemerintah desa.

Hasil uji $\mathrm{F}$ dapat diperoleh melalui tabel analisis varians (Anova) seperti yang terlihat pada tabel 11:

\section{Tabel 11 Uji F ANOVA $^{\mathrm{a}}$}

Berdasarkan tabel 11 tersebut diketahui hasil pengujian menggunakan uji $\mathrm{F}$, diperoleh nilai $F_{\text {hitung }}$ sebesar 40,476, sedangkan nilai $F_{\text {tabel }}$ sebesar 2,68. Maka $\mathrm{F}_{\text {hitung }}>\mathrm{F}_{\text {tabel }}(40,476>2,68)$ dengan nilai signifikansi $\mathrm{F}$ sebesar $0,00<0,05$. Hal ini berarti bahwa $\mathrm{H}_{0}$ ditolak dan $\mathrm{H} \alpha$ diterima.

2. Pengaruh Transparansi, Akuntabiliats dan Partisipasi Secara Parsial Terhadap Pengelolaan Dana Pemerintah Desa

Pengujian ini dilaksanakan untuk mengetahui pengaruh secara parsial transparansi, akuntabilitas dan partisipasi terhadap pengelolaan dana pemerintah desa. 
Berikut ini adalah tabel uji t Hasil output SPSS :

\begin{tabular}{lrrrrr}
\multicolumn{7}{c}{ Tabel 12 Uji t } \\
Coefficients
\end{tabular}

a. Dependent Variable: pengelolaan dana pemerintah desa Sumber: Output pengolahan data, SPSS 22, 2017

Berdasarkan tabel $\mathrm{t}$ tersebut nilai $t_{\text {hitung }}$ untuk transparansi sebesar 4,861. nilai thitung untuk akuntabilitas sebesar 2,752, dan nilai $t_{\text {hitung }}$ untuk partisipasi sebesar 2,112, Hal ini berarti bahwa $\mathrm{H}_{\mathrm{o}}$ ditolak dan $\mathrm{H}_{\mathrm{a}}$ diterima.

\section{Koefisien Determinasi}

Koefesien determinasi dilaksanakan untuk melihat besarnya kontribusi variabel penerapan transparansi, akuntabilitas dan partisipasi terhadap pengelolaan dana pemerintah desa. Koefesien determinasi diperoleh dengan cara mengkuadratkan koefesien korelasi yang telah ditemukan, dan selanjutnya dikalikan $100 \% \quad\left(r^{2} \times\right.$ $100 \%$ ) atau dengan langsung melihat nilai $\mathrm{R}$ Square $\left(\mathrm{R}^{2}\right)$. Untuk hasil analisis koefesien determinasi pada tabel 13 dibwah ini:

Tabel 13 Koefisien Determinasi $\mathbf{R}^{2}$ Model Summary ${ }^{b}$

\begin{tabular}{lrrrrr} 
Model & R & R Square & Adjusted R Square & Std. Error of the Estimate \\
\hline 1 & $.715^{\text {a }}$ & .511 & .499 & 1.468
\end{tabular}

a. Predictors: (Constant), partisipasi, akuntabilitas, transparansi

b. Dependent Variable: pengelolaan dana pemerintah desa

Sumber: Output pengolahan data dengan SPSS 22, 2017 
Berdasarkan tabel 13 diatas, diperoleh angka $\mathrm{R}^{2}$ ( $R$ square) sebesar 0,511 atau $(51,1 \%)$. Hal ini menunjukan bahwa kontribusi transparansi, akuntabilitas dan partisipasi terhadap pengelolaan dana pemerintah desa sebesar $51,1 \%$, sedangkan sisanya $48,9 \%$ dipengaruhi oleh variabel lain.

Standard Error of the Estimate merupakan suatu ukuran banyaknya kesalahan model regresi dalam memprediksikan nilai Y. Dari hasil regresi di dapat nilai 1,468 satuan, ini berarti banyaknya kesalahan dalam prediksi pengelolaan dana pemerintah desa sebesar 1,468 satuan.

\section{Pembahasan \\ Karakteristik Responden}

Karakteristik responden pada penelitian didominasi oleh laki-laki sebanyak 93 orang, dengan usia responden berkisar antara 31-40 tahun, dengan masa kerja > 40 tahun, dan tingkat pendidikan SMA sebanyak 81 orang.

\section{Uji F}

Berdasarkan hasil uji $F$ dapat diartikan bahwa pengelolaan dana desa pada Kecamatan Babakan Madang, Sukaraja \& Kecamatan Ciawi telah sesuai dengan permendagri No 113 Tahun 2014 yang menyatakan bahwa keuangan desa di kelola berdasarkan asas transparansi, akuntabilitas dan partisipasi serta dilaksanakan dengan tertib \& disiplin anggaran. sehingga dengan menerapkan asas transparansi, akntabilitas dan partisipasi secara efektif dan bersamaan maka akan menghindari terjadinya kecurangan dalam pengelolaan dana desa serta dapat dikatakan bahwa tata kelola pemerintahannya sudah baik.

\section{Uji t}

\section{Pengaruh Transparansi}

Berdasarkan hasil uji parsial transparansi berpengaruh positif terhadap pengelolaan dana pemerintah desa. Hasil penelitian ini mendukung penelitian Riswanto (2016). Hal ini membuktikan bahwa transparansi yang diinformasikan kepada publik dan DPR dengan benar, sesuai dan seksama maka akan meningkatkan kinerja pemerintah daerah. Sehingga untuk meningkatkan kualitas penglolaan dana desa sesuai dengan yang diharapkan memerlukan penerapan peraturan yang telah ditetapkan.

\section{Pengaruh Akuntabilitas}

Berdasarkan hasil uji parsial akuntabilitas berpengaruh terhadap pengelolaan dana pemerintah desa. Adanya pengaruh akuntabilitas terhadap pengelolaan dana desa dikarenakan Kepala Desa mempertanggungjawabkan dan melaporkan pelaksanaan APBDesa secara tertib, kepada masyarakat maupun kepada pemerintahan, sesuai dengan peraturan perundang-undangan, mulai dari proses perencanaan, sampai dengan pertanggungjawaban. Hal ini mendukung penelitian yang dilakukan oleh Sustrawati (2016).

\section{Pengaruh Partisipasi}

Adanya pengaruh partisipasi terhadap pengelolaan dana pemerintah desa pada Kecamatan Babakan Madang, Sukaraja \& Ciawi di karena setiap tindakan dilakukan dengan melibatkan masyarakat baik secara langsung maupun tidak langsung. Partisipasi tersebut merupakan pedoman dan acuan wajib yang harus diterapkan dalam pengelolaan dana desa.

\section{KESIMPULAN DAN SARAN \\ Kesimpulan}

Dari hasil analisis data maka dapat disimpulan bahwa Karakteristik responden yaitu didominasi oleh laki-laki sebanyak 93 orang, dengan usia responden berkisar antara 31-40 tahun, dengan masa kerja > 40 tahun, serta tingkat pendidikan SMA sebanyak 81 orang. 
Transparansi, akuntabilitas dan partisipasi secara simultan berpengaruh terhadap pengelolaan dana pemerintah desa pada kec. Babakan Madang, Sukaraja dan Ciawi.

Transparansi, akuntabilitas dan partisipasi secara parsial berpengaruh terhadap pengelolaan dana pemerintah desa pada kec. Babakan Madang, Sukaraja dan Ciawi.

\section{Saran}

Berdasarkan hasil dan pembahasan serta beberapa kelemahan yang telah diuraikan, maka terdapat beberapa saran yang dapat diberikan penulis, yaitu sebagai berikut :

1. Pemerintah desa perlu melakukan pengkajian ulang terkait pengelolaan dana desa dengan lebih meningkatkan transparansi, akuntabilitas dan partisipasi secara optimal dan menyeluruh. Terutama tentang partisipasi masyarakat dalam setiap kegiatan yang dilakukan pemerintah desa, karena partisipasi masyarakat masih belum nampak terlihat. Terkait dengan peningkatan transparansi pemerintah dapat meningkatkanya dengan cara menginformasikan jumlah dana yang didapat dan jumlah dana yang disalurkan kesetiap kegiatan/pembangunan dengan memasang spanduk sumber pendapatan desa dan pengeluarkan dana desa yang digunakan dalam satu periode.

2. Untuk peneliti selanjutnya, disarankan agar melengkapi metode survei dengan wawancara guna meningkatkan kualitas jawaban serta keseriusan responden dalam menjawab pernyataan yang diajukan sehingga terhindar dari biasnya jawaban responden. Untuk peneliti selanjutnya disarankan menambah variabel-variabel lain yang dapat memberikan pengaruh lebih besar terhadap pengelolaan dana pemeritah desa seperti variabel tingkat pendidikan dan peran perangkat desa.

\section{DAFTAR PUSTAKA}

Bastian, Indra. 2010. Akuntansi Sektor

Publik. Edisi Ketiga. Erlangga.

Jakarta.

Ghozali, Imam. 2011. Aplikasi Analisis Multivariate Dengan Program IBM

SPSS 17, Cetakan Kelima, Semarang:

Badan Penerbit Universitas

Diponegoro

Mardiasmo. 2009. Akuntansi Sektor

Publk. Andi.Yogyajarta.

2002.Akuntansi Sektor Publik,

Andi, Yogyakarta

Riswanto, Natak. 2016. Analisis Pengaruh

Akuntabilitas Dan Transparansi

Pengelolaan Keuangan Daerah

Terhadap Kinerja Pemerintah

Daerah Kabupaten Jember. Jurusan

Akuntansi, Fakultas Ekonomi,

Universitas Jember

Republik Indonesia. 2014. UU No. 6 Tahun 2014 Tentang Desa

. 2014. Permendagri No.113 Tahun

2014 Tentang Pedoman Pengelolan

Keuangan Desa. Berita Negara

Rerpblik Indonesia Nomor 2093.

Sekretariat Negara. Jakarta.

Renyowijoyo, Muindro. 2008. Akuntansi

Sektor Publik; Organisasi Non Laba.

Jakarta: Mitra Wacana Media.

2010. akuntansi sektor publik: organisasi non laba, edisi 2 ,mitra wacana media, jakarta.

Saroso, Samiaji. 2012. Penelitian Kualitatif: Dasar-dasar. Jakarta. Indeks

Sutrawati STB Kadek. 2016. Peran Perangkat Desa dalam Akuntabilitas Pengelolaan Dana Desa Studi pada Desa Pudaria Jaya Kecamatan Moramo. Jurusan Akuntansi Skripsi Fakultas Ekonomi 
Dan Bisnis. Universitas Halu Oleo. Kendari.

Sugiyono. 2010, Statistika untuk

Penelitian. Alfabeta. Bandung.

2013, Metode Penelitian

Kombinasi. Edisi Tiga. Alfabeta.

Bandung.

2014. Cara Mudah Menyusun:

Skripi, Tesis. dan Disertasi.

Alfabeta. Bandung.

Peraturan Pemerintah No 8 tahun 2016.

Pasal 1 angka 2 Tentang Dana Desa 